\title{
Neurological Disease associated with Folate Deficiency
}

\author{
E. H. REYNOLDS, P. ROTHFELD, JONATHEN H. PINCUS
}

British Medical fournal, 1973, 2, 398-400

\section{Summary}

In a general medical hospital population the neurological status of 24 patients with severe folate deficiency was compared with that of a control group of 21 patients with normal serum folate. A significant increase of organic brain syndrome and pyramidal tract damage was found in the folate-deficient group. These findings were independent of the degree of anaemia or the presence of alcoholism. These data are consistent with the view that severe folate deficiency may cause neurological deficits.

\section{Introduction}

Although it is well known that vitamin $B_{12}$ deficiency may cause neurological complications (Brain and Walton, 1969; Chanarin, 1969) the effect of folic acid deficiency on the nervous system is uncertain. For example, Brain and Walton (1969) suggested that "estimation of the serum folate should be carried out in cases of unexplained polyneuropathy, myelopathy, and dementia, although the exact role of folate deficiency in these disorders remains to be determined."

There are several reasons for further exploration of the relation between neurological disease and folate deficiency. (1) Folate deficiency results in a haematological disturbance (megaloblastosis), which is morphologically indistinguishable from that due to vitamin $B_{12}$ deficiency. (2) Folate is selectively concentrated in the cerebrospinal fluid (C.S.F.) (Herbert and Zalusky, 1961) and the C.S.F. folate level is usually closely related to that in the serum (Reynolds et al., 1972). (3) It has been claimed that anticonvulsant-induced folate deficiency may result in neuropsychiatric complications in epileptic patients (Reynolds et al., 1966; Reynolds, 1972). (4) There are scattered case reports of reversible neurological disease associated with folate deficiency (Grant et al., 1965; Spillane, 1965; Strachan and Henderson, 1967) including two in which a clinical picture identical to that of subacute combined system degeneration was encountered (Ahmed, 1972; Pincus et al., 1972). (5) There are also reports of inborn errors of folate metabolism associated with mental retardation (Arakawa, 1970).

Nevertheless, folate deficiency commonly occurs without any associated neurological disease (as does vitamin $B_{12}$ deficiency) and although it is known that the administration of folic acid can precipitate neurological complications in patients with pernicious anaemia (Brain and Walton, 1969; Chanarin, 1969) it is not generally accepted that deficiency of this vitamin can occasionally result in disorders of the nervous system. As there are no reports of the prevalence of neurological disease associated

\footnotetext{
Department of Neurology, Yale University School of Medicine, New Haven, Connecticut 06510, U.S.A.

E. H. REYNOLDS, M.D., M.R.C.P., Visiting Associate Professor of Neurology (At present: Lecturer, University Department of Neurology, Institute of Psychiatry, Denmark Hill, London SE5 8AZ)

P. ROTHFELD, Medical Student

(Present address: University of North Carolina, Chapel Hill, North Carolina, U.S.A.)

JONATHEN H. PINCUS, M.D., Associate Professor
}

with folate deficiency, we undertook a preliminary study of this problem.

\section{Patients and Methods}

The neurological and mental state examination of 24 patients with severe folate deficiency (group A) was compared to that in an age- and sex-matched group of 21 patients without folate deficiency (group B) (see table I). All were acute admissions to the general medical service of the Yale-New Haven Hospital (34 patients) or the West Haven Veteran's Administration Hospital (11 patients). Patients admitted to the neurological or psychiatric service were not included.

TABLE I-Composition of the Two Groups. Group A-Patients with Severe Folate Deficiency (Serum Folate $<3 \mathrm{ng} / \mathrm{ml}$ ), Group B-Patients with Normal Folate (Serum Folate $>6.9 \mathrm{ng} / \mathrm{ml}$ )

\begin{tabular}{|c|c|c|c|c|}
\hline & & & $\begin{array}{c}\text { Group A } \\
(n=24)\end{array}$ & $\underset{(n=21)}{\text { Group B }}$ \\
\hline \multicolumn{3}{|c|}{ 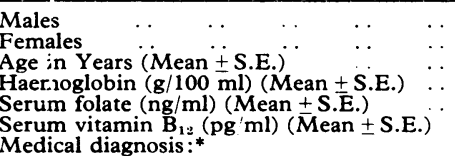 } & $\begin{array}{c}18 \\
6 \\
55 \pm 3 \cdot 5 \\
9 \cdot 7 \pm 0 \cdot 5+ \\
1 \cdot 6 \pm 0 \cdot 1 \S \\
805 \pm 121\end{array}$ & $\begin{array}{c}15 \\
6 \\
56 \cdot 8 \pm 2 \cdot 0 \\
12 \cdot 1 \pm 0 \cdot 5 \\
12 \cdot 7 \pm 1 \cdot 3 \\
872 \pm 190\end{array}$ \\
\hline Alcoholism & . $\quad \ldots$ & . & 12 & 8 \\
\hline $\begin{array}{l}\text { Diabetes mellitus.. } \\
\text { Malignant disease }\end{array}$ & $\cdots \quad \cdots$ & $\cdots$ & $\begin{array}{l}3 \\
3\end{array}$ & 4 \\
\hline Pulmonary disease & $\cdots$ & $\therefore$ & 3 & $\begin{array}{l}3 \\
2\end{array}$ \\
\hline Renal disease & $\ldots$ & . & 1 & 2 \\
\hline Partial gastrectomy & $\cdots$ & . & 2 & 1 \\
\hline Peptic ulcer & . & . & 1 & 2 \\
\hline Malnutrition $\dagger$ & . & . & 2 & 0 \\
\hline Malabsorption & $\therefore$ & $\therefore$ & 0 & 2 \\
\hline Iron-deficiency anaemia & $\ldots$ & $\therefore$ & 0 & 2 \\
\hline Heart failure & . & . & 1 & 1 \\
\hline Phlebitis & . & . & 1 & 0 \\
\hline Diverticulitis _. . & .. & . & 1 & 2 \\
\hline Ulcerative colitis. & $\therefore$ & $\therefore$ & 1 & 0 \\
\hline Amoebic dysentery & $\ldots \quad \ldots$ & $\ldots$ & 0 & 1 \\
\hline
\end{tabular}

* Some patients with more than one diagnosis.

+Excluding alcoholics.

$\stackrel{+\mathrm{P}}{\mathrm{P}}<0.01$.

For both hospitals the serum folate and vitamin $B_{12}$ assays are undertaken in the same laboratory, the former by the aseptic Lactobacillus casei method (Herbert, 1966), and the latter by the " 7 Co method (Tibbling, 1969). These are measured either at the request of the attending physician or routinely when the mean corpuscular volume exceeds $94 \mu^{3}$. The lower limit of the normal serum folate range is $7 \mathrm{ng} / \mathrm{ml}$. Values between 5 and $7 \mathrm{ng} / \mathrm{ml}$ are borderline. Only patients with serum folate values of less than $3 \mathrm{ng} / \mathrm{ml}$ (severe deficiency) were selected for study. The control group was composed of patients whose serum folate levels were $>6.9 \mathrm{ng} / \mathrm{ml}$.

A neurological examination was performed by at least two of the authors, without prior knowledge of the clinical problem, on each patient selected for study on the basis of a subnormal or normal serum folate. Particular attention was paid to the presence of an organic brain syndrome. This was evaluated by standard questions concerning orientation to time and place and the ability to subtract numbers serially, to interpret common proverbs and similarities, to remember seven numbers forward and three backward, and to name five cities in the United States. Neurological signs were recorded for analysis only if both examiners agreed. Mild to moderate impairment of vibration 
sense in the lower limbs in the elderly was not regarded as pathological unless accompanied by other signs. Five patients (two with folate deficiency and three controls) with disabling apathy and depression were included in the category of organic brain syndrome for the analysis of the data.

\section{Results}

The haemoglobin, serum folate, and vitamin $B_{12}$ levels and medical diagnosis in the folate deficient (group A) and control (group B) patients are summarized in table $I$.

Haemoglobin.-In group A, 23 patients were anaemic (haemoglobin $<12.5 \mathrm{~g} / 100 \mathrm{ml}$ ) and 12 of these had levels of $10 \mathrm{~g} /$ $100 \mathrm{ml}$ or less. In group B, 10 patients were anaemic and only two had levels of $10 \mathrm{~g} / 100 \mathrm{ml}$ or less $(P<0.01)$.

Vitamin $B_{12}$. - Only one patient (in group A) had a subnormal serum vitamin $B_{12}$ level. Her Schilling test was normal and no abnormality was found on neurological examination.

Medical Diagnosis. - Twelve patients in group A and eight in group B were alcoholics. This diagnosis was based on a history of constant alcohol consumption leading to loss of work or disruption of home life, usually associated with clinical, biochemical, or biopsy evidence of liver disease. Group A included three patients with diabetes (two of whom were alcoholic), three with malignant disease (breast, prostate, submandibular), two with previous partial gastrectomies (one an alcoholic), two with malnutrition, and one with chronic renal disease. Group B included four diabetics (two were alcoholic), three with malignant disease (breast, colon, pancreas), one with previous partial gastrectomy (an alcoholic), two with chronic renal disease, and two with malabsorption. Other individual diagnoses in both groups are recorded in table $\mathrm{I}$.

TABLE II-Comparison of Neurological Findings in Folate Deficient Group $(A)$ and Normal Folate Control Group (B)

\begin{tabular}{|c|c|c|c|c|}
\hline & & $\underset{(n=24)}{\text { Group } A}$ & $\underset{(n=21)}{\text { Group B }}$ & Significance \\
\hline $\begin{array}{l}\text { Organic brain syndrome } \\
\text { Cerebellar syndrome .. } \\
\text { Neuropathy } \\
\text { Positive Babinski response }\end{array}$ & $\begin{array}{ll}\cdots & \cdots \\
\cdots & \cdots \\
\cdots & \cdots\end{array}$ & $\begin{array}{r}17\left(70 \cdot 8^{\circ}{ }_{0}\right) \\
3\left(12 \cdot 5^{\circ} \%\right) \\
14\left(58 \cdot 33^{\circ}\right) \\
5\left(20 \cdot 8{ }^{\circ}\right)\end{array}$ & $\begin{array}{l}8\left(39 \cdot 0^{\circ}{ }_{0}\right) \\
1\left(4 \cdot 8^{\circ}{ }_{0}\right) \\
7\left(33^{\circ} \cdot 3^{\circ}{ }_{11}\right) \\
0\end{array}$ & $\begin{array}{l}P<0.03 \\
\text { N.S. } \\
\text { N.S. } \\
P<0.03\end{array}$ \\
\hline
\end{tabular}

N.S. $=$ Not significant .

Neurological Findings.-Comparison of the findings in the two groups is summarized in table II. In group A there is a significant increase in the incidence of organic brain syndrome $(P<0.03)$ and positive Babinski response $(P<0.03)$. The incidence of neuropathy is also higher in group $\mathrm{A}$, but this falls just short of significance. To assess the influence of anaemia the 12 patients in group A with haemoglobin levels of $10 \mathrm{~g} / 100 \mathrm{ml}$ or less were compared with the 12 patients in the same group with levels above $10 \mathrm{~g} / 100 \mathrm{ml}$. The incidence of organic brain syndrome, cerebellar syndrome, neuropathy, and positive Babinski response did not differ in these two subgroups. In view of the known association of alcoholism with neurological disease the alcoholic and non-alcoholic patients in each group were separately compared. In the non-alcoholic patients there was again a significant increase in organic brain syndrome and positive

TABLE III-Comparison of Neurological Findings in Non-alcoholic Patients with Low Folate (Group A) and Non-alcoholics with Normal Folate (Group B)

\begin{tabular}{|c|c|c|c|c|c|}
\hline & & & $\begin{array}{c}\text { Group } A \\
(n=12)\end{array}$ & $\underset{(n=13)}{\text { Group } B}$ & Significance \\
\hline $\begin{array}{l}\text { Organic brain syndrome } \\
\text { Cerebellar syndrome } \\
\text { Neuropathy } \\
\text { Positive Babinski response }\end{array}$ & $\begin{array}{l}\cdots \\
\cdots \\
\cdots\end{array}$ & $\begin{array}{l}\cdots \\
\cdots \\
\cdots\end{array}$ & $\begin{array}{l}9(75 \%) \\
0 \\
4(33 \cdot 3 \%) \\
4(33 \cdot 3 \%)\end{array}$ & $\begin{array}{c}5(38 \cdot 5 \%) \\
0 \\
3(23 \cdot 1 \%) \\
0\end{array}$ & $\begin{array}{l}P<0.05 \\
\text { N.S. } \\
\text { N.S. } \\
P<0.05\end{array}$ \\
\hline
\end{tabular}

N.S. $=$ Not significant.
TABLE IV-Comparison of Neurological Findings in Group $A$ Alcoholic and Non-alcoholic Patients with Folate Deficiency

\begin{tabular}{|c|c|c|c|c|}
\hline & & $\begin{array}{l}\text { Alcoholic } \\
(n=12)\end{array}$ & $\begin{array}{c}\text { Non-alcoholic } \\
(n=12)\end{array}$ & Significance \\
\hline $\begin{array}{l}\text { Organic brain syndrome } \\
\text { Cerebellar syndrome } \\
\text { Neuropathy } \\
\text { Positive Babinski response }\end{array}$ & $\begin{array}{l}\cdots \\
\cdots \\
\cdots \\
\cdots\end{array}$ & $\begin{array}{r}8(66 \cdot 7 \%) \\
3(25 \%) \\
10(83 \cdot 3 \%) \\
1(8 \cdot 3 \%)\end{array}$ & $\begin{array}{c}9(75 \%) \\
0 \\
4(33.3 \%) \\
4(33 \cdot 3 \%)\end{array}$ & $\begin{array}{l}\text { N.S. } \\
\text { N.S. } \\
\text { P<0.05 } \\
\text { N.S. }\end{array}$ \\
\hline
\end{tabular}

N.S. $=$ Not significant.

TABLE V-Summary of Patients with Medical Diagnoses not usually associated with Neurological Complications

\begin{tabular}{|c|c|c|}
\hline $\begin{array}{l}\text { Case } \\
\text { No. }\end{array}$ & Medical Diagnosis & Neurological Findings \\
\hline \multicolumn{3}{|c|}{ Folate Deficient Group $(A)$} \\
\hline $\begin{array}{l}1 \\
2 \\
3 \\
4\end{array}$ & \multirow{2}{*}{$\begin{array}{l}\text { Phlebitis } \\
\text { Pneumonia } \\
\text { Ulcerative colitis } \\
\text { Submandibular tumour } \\
\text { (non-metastatic) } \\
\text { Carcinoma of prostate } \\
\text { (non-metastatic) }\end{array}$} & $\begin{array}{l}\text { Organic brain syndrome } \\
\text { Normal } \\
\text { Sensorimotor neuropathy }\end{array}$ \\
\hline 5 & & $\begin{array}{l}\text { Organic brain syndrome } \\
\text { Organic brain syndrome. } \\
\text { Sensorimotor neuropthy }\end{array}$ \\
\hline \multirow[t]{2}{*}{6} & Pulmonary disease & $\begin{array}{l}\text { Organic brain syndrome. } \\
\text { Positive Babinski response }\end{array}$ \\
\hline & \multicolumn{2}{|c|}{ Normal Folate Group $(B)$} \\
\hline $\begin{array}{l}1 \\
2 \\
3\end{array}$ & $\begin{array}{l}\text { Iron-deficiency anaemia } \\
\text { Amoebic dysentery } \\
\text { Carcinoma of pancreas }\end{array}$ & $\begin{array}{l}\text { Retarded depression } \\
\text { Normal }\end{array}$ \\
\hline $\begin{array}{l}4 \\
5 \\
6\end{array}$ & $\begin{array}{l}\text { (non-metastatic) } \\
\text { Gastrointestinal bleeding (ulcer) } \\
\text { Iron-deficiency anaemia } \\
\text { Pulmonary disease }\end{array}$ & $\begin{array}{l}\text { Normal } \\
\text { Normal } \\
\text { Normal } \\
\text { Normal }\end{array}$ \\
\hline
\end{tabular}

Babinski response in group A (table III). Among the alcoholic patients there was a somewhat higher incidence of neurological abnormalities of all types if group A was compared with group $B$, but this did not reach significant levels. In group $A$ the alcoholic patients were compared with the non-alcoholic patients (table IV). The incidence of organic brain syndrome and positive Babinski response was similar in the two subgroups, but cerebellar syndrome and neuropathy were more common in the alcoholic subgroup. Finally, we compared patients in each group with medical diagnoses which are not usually associated with neurological complications (table $\mathrm{V}$ ). Of six such patients in group A five had neurological abnormalities, whereas of six comparable patients in group $B$ all were neurologically normal except for one patient with severe retarded depression $(P<0.05)$.

\section{Discussion}

Comparison of the two groups as a whole showed a significant increase in organic brain syndrome and pyramidal tract damage together with a higher prevalence of neuropathy in the folatedeficient patients. However, several factors have to be considered in the evaluation of these observations.

The folate-deficient group was, as expected, significantly more anaemic than the control group, but there was no evidence that anaemia per se influenced the neurological findings. Comparison of patients with haemoglobin levels greater than $10 \mathrm{~g}$ $100 \mathrm{ml}$ also showed a similar increase in organic brain syndrome and pyramidal tract damage in the folate-deficient group. Furthermore, in the folate-deficient group the neurological findings were similar in patients with haemoglobin levels above and below $10 \mathrm{~g} / 100 \mathrm{ml}$.

Alcoholism is a well known cause of both neurological complications (Victor et al., 1971) and folate deficiency (Chanarin, 1969), and the unexpectedly high number of alcoholics in both our groups necessitated separate analysis of these patients. We found a higher incidence of neurological disorders of all types in the folate-deficient alcoholics as compared with control alcoholics, but this did not reach significant proportions possibly because of the small numbers involved. Among nonalcoholics there was a significant increase in organic brain syn- 
drome and pyramidal tract damage in the folate-deficient patients. When we compared alcoholic with non-alcoholic folate-deficient patients the incidence of organic brain syndrome and positive Babinski response was similar in the two subgroups, but cerebellar syndrome and neuropathy were more common in alcoholics, suggesting that the trend towards an increase of neuropathy with folate deficiency (table II) may have been more a function of alcoholism than folate deficiency alone.

Both folate-deficient and control groups also contained patients with other medical conditions known to cause neurological complications (malignant disease, diabetes, partial gastrectomy, chronic renal disease, malabsorption, and malnutrition). These diagnoses, however, were fairly evenly distributed between the two groups. Furthermore, after these patients and the alcoholics were excluded there was again a remarkable increase of neurological complications in the remaining folate-deficient patients even though the numbers in each group were small (table V).

It is difficult to draw conclusions about the relation between folate deficiency and neurological disease in patients whose neurological disorders, even in individual cases, are probably multifactorial in origin. Although it is probable (1) that organic neurological disease can lead to folate deficiency as a result of dietary deficiency (Batata et al., 1967) and (2) that nutritional factors were an important cause of deficiency in many of our patients, our findings are also consistent with the hypothesis that folate deficiency can in certain circumstances result in neurological complications, in particular organic brain syndrome and pyramidal tract damage. Our data provides encouragement for more detailed studies in larger and more homogeneous populations. Little is known about the biochemical basis of the neurological complications of alcoholism apart from the role of thiamine (Victor et al., 1971), and the possible contribution of folate deficiency deserves further evaluation.

Among additional factors which might possibly have contributed to the neurological problems in the present study we only assessed the role of vitamin $B_{12}$. Only one patient was vitamin $B_{12}$ deficient and her neurological examination showed nothing abnormal. In our understanding of the effects of either folic acid or vitamin $B_{12}$ deficiency on the nervous system an explanation is required for the many instances with either vitamin deficiency in which no neuropsychiatric disturbance is found. This may reflect, at least in part, variations in the severity and duration of the deficiency. Although the serum folate level may not always be a good guide to the folate status of the patient, in this study we deliberately chose patients with very low serum values. It is clear that these patients were indeed folate deficient as all except one had a macrocytic anaemia. However, a further problem with this type of study is the uncertain relation of serum folate to brain folate. Although a good correlation between serum and C.S.F. folate concentrations has been found (Reynolds et al., 1972), it has yet to be shown that this is necessarily reflected in changes in brain folate. There is experimental evidence, however, that folate deficiency can impair cerebral nucleic acid metabolism (Haltia, 1970).

We are grateful to Professor G. H. Glaser for his advice and support, and to Dr. M. Barnes for the vitamin assays. This work was supported by funds from U.S.P.H.S. 5 PO1 NS 06208-06.

\section{References}

Ahmed, M. (1972). British Medical fournal, 1, 181.

Arakawa, T. (1970). American fournal of Medicine, 48, 594

Batata, M., Spray, G. H., Bolton, F. G., Higgins, G., and Wollner, L. (1967). British Medical fournal, 2, 667.

Brain, Lord, and Walton, J. N. (1969). Brain's Diseases of the Nervous System. London, Oxford University Press.

Chanarin, I. (1969). The Megaloblastic Anaemias. Oxford, Blackwell Scientific Grant, M. C., Hoffbrand, A. V., and Wells, D. G. (1965). Lancet, 2, 763. Grant, M. C., Hoffbrand, A. V., and Wells, D. G. (1965). Lancet, 2,
Haltia, M. (1970). British fournal of Experimental Pathology, 51, 191.

Haltia, M. (1970). British Fournal of Experimental Pathology, 51, 191.

Herbert, V., and Zalusky, R. (1961). Federation Proceedings,

Pincus, J., Reynolds, E. H., and Glaser, G. H. (1972). Fournal of the American Medical Association, 221, 496.

Reynolds, E. H., Chanarin, I., Milner, G., and Matthews, D. M. (1966). Epilepsia, 7,261.

Reynolds, E. H., Gallagher, B. B., Mattson, R. H., Bowers, M., and Johnson, A. L. (1972). Nature, 240, 155.

Reynolds, E. H. (1972). In Anti-epileptic Drugs, ed. D. M. Woodbury, J. K. Penry, and R. P. Schmidt. New York, Raven Press.

Spillane, J. D., cited by Wells, C. E. C. (1965). Proceedings of the Royal Society of Medicine, 58, 721 .

Strachan, R., and Henderson, J. (1967). Quarterly fournal of Medicine, 36, 189.

Tibbling, G. (1969). Clinica Chimica Acta, 23, 209.

Victor, M., Adams, R. D, and Collins, G. H. (1971). The WernickeKorsakoff Syndrome. Contemporary Neurology Series No. 7. Oxford, Blackwell Scientific.

\section{MEDICAL MEMORANDA}

\section{Contamination of E.C.G. Electrode Pads with Klebsiella and Pseudomonas Species}

\author{
EUNICE LOCKEY， J. PARKER， M. W. CASEWELL
}

British Medical fournal, 1973, 2, 400-401

Any moist site in the hospital environment provides a potential site for the survival and multiplication of Gram-negative bacilli, particularly Pseudomonas species (Parker et al., 1971).
The important reservoirs and routes of infection for Klebsiella species have not been so clearly defined. Until recently, epidemiological studies have been hindered by there being no centre for klebsiella typing in this country (Lancet, 1967). Important hospital epidemics with Klebsiella species have shown some sources, including a hand-cream dispenser (Morse, et al., 1967), aerosol solutions used in respiratory apparatus (Mertz et al., 1967), and intravenous fluids (Sack, 1970; House of Commons, 1972).

Any new reservoir or unfamiliar route for these organisms presents a particular threat to the patient. We report here a patient with klebsiella septicaemia, associated with contamination of saline used to moisten his electrocardiograph (E.C.G.) electrode pads, as well as the contamination of commercially prepared electrode pads with Pseudomonas aeruginosa.
National Heart Hospital, London W1M 8BA

EUNICE LOCKEY, M.D., F.R.C.PATH., Consultant Pathologist

J. PARKER, F.R.C.S., M.R.C.P., Consultant Surgeon

St. Thomas's Hospital Medical School, London SE1 7EH

M. W. CASEWELL, M.B., B.SC., Lecturer in Microbiology

\section{Case Report}

On 22 September 1972 a 43-year-old man with extensive coronary artery disease underwent a triple saphenous vein, aorta to coronary artery, bypass graft operation using cardiopulmonary bypass. Vein grafts were taken from the lower leg. Antibiotic cover started with the premedication and consisted of gentamicin $120 \mathrm{mg}$ intramuscularly 